Trivent Publishing

(C) The Authors, 2016

Available online at http://trivent-publishing.eu/

Series: Philosophy, Communication, Media Sciences

Volume: Communication Today: An Overview from Online Journalism to Applied Philosophy

\title{
Knowledge as a Social Construct in Philosophy with Children
}

\author{
Florin Lobont \\ Department of Philosophy and Communication Sciences, West University of Timisoara, Romania. \\ florin.lobont@e-uvt.ro
}

\begin{abstract}
The paper aims to present some of the principles of Philosophy for/with children that arguably lead to some simple, everyday practices to help children and young people become thoughtful, curious and reasonable. We will argue that Philosophy for or with Children's central pedagogical tool is the community of inquiry, showing the positive role this structure plays in combating what is perceived to be a drift in society to the idea that opinions cannot be judged and do not need to be justified. This type of community will be presented as a context for facilitating personal relationships inspired by a sense of participative democracy, an effective instrument that can be employed in service of an intellectual endeavour which rests on the concept of knowledge as a continuous and fertile intersubjective change rather than as a mere transfer of information.
\end{abstract}

\section{Keywords}

Philosophy for/with Children; community of inquiry; children's thinking facilitation; thinking skills; cooperative skills.

This is an Open Access article distributed in accordance with the Creative Commons Attribution Non Commercial (CC-BYNC-ND 4.0) license, which permits others to copy or share the article, provided original work is properly cited and that this is not done for commercial purposes. Users may not remix, transform, or build upon the material and may not distribute the modified material (http://creativecommons.org/licenses/by-nc/4.0/)

DOI: 10.22618/TP.PCMS.20164.349026 


\section{The need for Philosophy for/with Children}

Despite several reforming attempts of the Romanian education system, critics strongly emphasize "the perpetuation of a great deal of ineffective, rigid, unpractical, and sterile educational practices as a result of the continuous primacy of the traditional educational paradigm, whose main characteristics are: 1) education consists essentially of knowledge transmission; 2) knowledge is unambiguous, unequivocal and un-mysterious; 3) knowledge is divided into non-overlapping disciplines; 4) teachers are/should be authoritative sources of knowledge."1

But Romania is not an isolated case. In recent years a large number of studies stress the low compatibility between the various national education systems' outcomes and the requirements of a modern and increasingly dynamic, flexible and diverse modern conglomerate of societies and economies. Despite various curricular reforms, critics strongly emphasise the perpetuation of a great deal of ineffective, rigid, unpractical, and sterile educational practises as a result of the continuous primacy of the traditional educational paradigm. ${ }^{2}$ On the other hand, the most recent UN and EU development needs prospects show, social innovation will be increasingly needed, as one of the most important future resources.

The attainment of his goal requires a fundamental shift in young generation's views on knowledge, change, community, diversity, initiative, environment, and other related realities. In our opinion Philosophy for Children, P4C, and its development as Philosophy with Children (PwC), increases significantly the chances of producing these changes. They are more than simple programs of stimulating and fostering thinking abilities. Instead, they comprise a complex of specific resources and methods of tapping into, and encouraging, children's curiosity, helping them in their search for meaning, stimulates and develops their intellectual courage and helps them develop rigorously skills that enable them to make correct judgments in their day-to-day lives. In the countries where this visionary set of philosophical abilities training is already becoming a tradition, the result is an increasing number of assertive young people, capable to relate critically-constructively to knowledge, to articulate and conceptualize their ideas and think independently and innovatively, to be tolerant toward others' ideas and beliefs, to work within innovative groups of likeminded people - in other words, to be consistently different.

The Philosophy for, or with, Children's central pedagogical tool is the community of inquiry, a structure that can play a crucial role in "combating what is perceived to be a drift in society to the idea that opinions cannot be judged and do not need to be justified." This type of community represents ,a context for discussion wherein participants are challenged to justify their opinions regularly." "3 The community of inquiry "aims at understanding the issues in question or the beliefs of other participants. Argument is seen as a collaborative effort to come to the best answer to a question." Teachers specialized in $\mathrm{P} 4 \mathrm{C}$ develop their class towards becoming a community of inquiry by some straightforward practices. In order to explain them, these practices are generally organized in four categories: encourage questioning, develop concepts, encourage dialogue and argument, and work for reasonableness. ${ }^{4}$

As an attempt to contribute to the solving of the problems derived from national education system's low adaptability to present day's dynamics and requirements, we resort to philosophy for children as a

\footnotetext{
${ }^{1}$ Daniela Dumitru, "Communities of inquiry. A method to teach," in Procedia - Social and Behavioral Sciences 33 (2012): 239

${ }^{2}$ Scott Gerber, "Here is the real problem with the American educational system," in Time, 2 June 2014, http://time.com/2806663/american-education/ (accessed June 20, 2015).

${ }^{3} \mathrm{http}: / / \mathrm{p} 4 \mathrm{c} . \mathrm{com} / \mathrm{teachers}-$ guide (accessed May 20, 2015).

${ }^{4}$ Ibidem.
} 
fast developing provider of a whole and coherent approach to learning and knowledge in general, and a ground for innovative thinking. Philosophical inquiry is a powerful practice, which provides children properly guided by adequately trained educators-facilitators, the opportunity to ask questions and explore issues, concepts and ideas - adapted to their specific age - that are important and relevant to them. By participating in $\mathrm{P} 4 \mathrm{C}$ activities children "acquire the habit to ask from each other arguments and opinions, to listen carefully to each other, to build on the ideas of others. ${ }^{5}$ According to the founder of Philosophy for Children (P4C) Matthew Lipman, P4C's mission is "to help children learn how to think for themselves," via "improvement of reasoning ability; development of creativity; personal and interpersonal growth; and development of ethical understanding." ${ }^{\prime 6}$

The object of Philosophy for/with Children includes those common but also questionable concepts that lie both at the basis of our life experience and that of academic disciplines. These concepts include: truth, reality, knowledge, evidence, freedom, friendship, rights, mind, identity, love, rules, responsibility, action, beauty, logic, language, fairness, thinking, reason, existence, possibility beauty, meaning, purpose, time, God, infinity, human nature. They are themes dealt with by philosophy, which children take great interest and pleasure in reflecting upon and discussion. They can be helped to identify these ideas and concerns in especially written stories, as well in traditional stories, novels or movies for children. During the philosophy for/with children classes such themes are subjected to investigation procedures within the community of inquiry that resort to instruments of philosophical reasoning and imaginative exploration under the guidance of a teacher whose role is to stimulate children to think.

According to M.R. Paine, "learning or practicing thinking skills is not a linear, sequential progression or process, but rather a spiral, the requirements for good thinking can nonetheless be itemized as

- Forming questions.

- Making distinctions - critical thinking.

- Exploring concepts/concept formation.

- Following and making an argument - logic.

- Enquiry skills."7

Being aware of the necessity of introducing such a postgraduate program in Romania, we designed, within the Faculty of Political Sciences, Philosophy and Communication Sciences, a postgraduate course (which will be briefly described in Part III) aiming to provide educators and teachers with the skills of facilitating philosophical reflection and exploration by children between the ages of 5 and 14 . The state of the art methodology we found in international literature and training modules was adapted to the realities of Romania on the basis of experimental lessons conducted with children of various ages in schools from Timisoara. Even from their first encounter with this form of reflective inquiry, children aged between 5 and 10 demonstrated a high level of engagement and curiosity to explore issues of philosophical nature that obviously preoccupy them (sometimes seriously) and to which they have not found satisfactory answers or encouraging exploratory contexts. As for the older students (12 and older) who had not had any previous encounter with Philosophy for, or with, Children, their reluctance to let themselves drawn into philosophical discussions and their social discomfort when attempting to engage jointly in reflection as a group of peers indicates the need for an earlier start of and acquainting with this type of inquiry. This need appeared to us as imperative, as at this age the youngsters' social programming as followers of the non-independent, uncritical, passive, individualistic and reproductive approach to learning based on domain fragmentation and teacher's

\footnotetext{
5 Institute for the Advancement of Philosophy for Children (IAPC), http://74.125.153.132/search?q=cache: VjzVFd9bdC0J:cehs.montclair.edu/academic/iapc/Catalogue_Final.pdf+institute+for+the+advancement+of+ society+for+children\&cd=8\&hl=en\&ct=clnk (accessed January 24, 2015).

${ }^{6}$ Matthew Lipman, A. M. Sharp and F. S. Oscanyan, Philosophy in the Classroom. 2nd edition (Philadelphia: Temple University Press, 1980), 53, 78.

${ }^{7}$ R. P. Martin, "The Pedagogy of Philosophy for Children/Philosophical Enquiry," research paper (University of York, 2012), http://etheses.whiterose.ac.uk/3971/1/MRPaineMAeducDisV3.pdf (accessed December 1, 2015), 15.
} 
authority, had already set in to a worrying extent. According to our observations, the dynamic of the school class-based groups long shaped by this directive polarized approach, induces a visible sense of awkwardness in pupils when they are invited to reflect and talk about "big questions" (which they have learned to suppress as ridiculous or irrelevant, if not nonsensical) that lack pre-existent answers and do not seem to have definitive and unique resolutions.

Nevertheless, it is never too late for regaining at least a (good) part of teenagers' intellectual curiosity and courage, and sense of wonder from an earlier age. No effort is too big to achieve this, as it was demonstrated by our persistent and patient attempts to bring up and constantly reformulate (and contextually adapt to the pupils' age-specific mental frameworks) big life issues dealt with by philosophy, such as truth, knowledge, freedom, friendship, rights, mind, identity, love, rules, responsibility, time, God, infinity, death, and such likes. If the teacher manages to reach deep down to their concealed selves and help them open to such things by making them feel it's a natural and worthwhile process, they show that they care deeply about such questions and wish to seek answers to them.

We based our attempts to help mediate adolescents' acquaintance with philosophical inquiry on research carried out by highly experienced practitioners of philosophy with adolescents in communities of inquiry, primarily Patricia Hannam and Eugenio Echeverria. In assessing the specific difficulties that many teenagers are facing, they conclude: "Adolescents with diffused identities are not interested in confronting their developmental tasks and can fall into behaviours suggesting mental illness." 8 As a result,

These adolescents have low self-esteem and are often used by their peers to engage in anti-social behavior. They start losing interest in school and in their personal health-care, [enter a state apathy, and withdraw from their normal life activities,] showing clear signs of depression. They are also readily influenced by whatever is in fashion in terms of sects or groups that promise them salvation, belonging and acceptance by a group of peers as long as they do what the leader says. The community of philosophical inquiry serves as stable space for these cases. Sometimes it is the only stable place they know where they can analyse alternatives, feel accepted and respected and ask for advice from their peers. In general terms, it acts as a safe haven in the midst of the storm. ${ }^{9}$

\section{The community of inquiry}

The central pedagogical-methodological tool of $\mathrm{PwC} / \mathrm{P} 4 \mathrm{C}$ is the community of inquiry. Within this particular type of collectivity students work together to generate and subsequently answer their own questions about the philosophical issues contained in the materials written for this purpose, or in a variety of other resources such as images and recordings useful to the stimulation of group exploring of issues. In essence, such a structure's joint thinking is investigative - as collective effort dedicated to finding solutions -; cooperative - that is, capable to promote among members a genuine opening toward each other's arguments and reasons, and to view every gained piece of knowledge as a fruit of "communicative action" -, and individualized - able to acknowledge and respect the diversity of argued positions. ${ }^{10}$

The community of philosophical enquiry's epistemological standpoint is that "the examination, facilitated by a philosophically educated person, analyses and reconstructs positions or claims through the dialogical distributed thinking, by employing, among other means, critical thinking, thought experiments, and the uncovering of fallacies and underlying argumentation forms." Owing to their potential, "this structure proved its utility far beyond philosophical disciplines: ... significant research

\footnotetext{
${ }^{8}$ Patricia Hannam and Eugenio Echeverria, Philosophy with Teenagers: Nurturing a moral imagination for the $21^{\text {st }}$ century (New York and London: Network Continuum, 2009), 22.

${ }^{9}$ Ibidem

${ }^{10}$ Pierpaolo Casarin, "The fifth national training course in 'Philosophy for Children," in Pratiche filosofiche 1(2) (2003): 88.
} 
in the field showed that they are a highly effective mode of teaching and ... reflecting across most disciplines of the curriculum, providing students with a range of generic skills, such as the ability to evaluate arguments and appropriately weigh different forms of evidence."11

Thinking within the community of enquiry is critical, creative, based on conversation and dialogue, and attentive to the opinions and feelings of others. Within these groups students learn to respect, listen and understand a wide range of views. The process of philosophical exploration conducted in this environment encourages students to take increased responsibility for their own learning and develop independent, self-corrective thinking skills. Philosophy for Children achieves these goals by providing children with the opportunity to reflect on ideas and concepts they themselves choose because they find them interesting and worth exploring. As the high-quality website and open source portal dedicated to philosophy for children Philosophy for Children New Zealand puts it, they are driven by questions such as: Who has a mind? How should we treat our friends? What is a just society? What does it mean to know something? What is a good reason to do or decide anything? Do we own our own bodies? ${ }^{12}$

The discussions with pupils within the communities of inquiry are not simple exchanges of views, but are aimed at building the best answer to the questions posed, and the best answers are not provided or validated by the educator/facilitator. Instead, the class gradually assumes responsibility for constructing and evaluating the diversity of possible answers to a question. Within the group, each individual learns to express their ideas while taking into account different perspectives. Philosophy for/with children does not start from the presupposition that there are no right or wrong answers, but from that that even though definitive answers are hard or impossible to find, some can be more reasonably defended than others. Tolerance, ability to work together constructively and the ability to explore, build, express and conceptualize thoughts and ideas, are the main results needed both by individuals and societies, with their educational systems aiming to educate older students in order to be increasingly functional, innovative and rapidly adaptable to the continuous challenges the world faces at an ever increasing pace.

Our own experience of promotional demonstrative $\mathrm{PwC}$ lessons in various schools in Timisoara unveiled, to the assisting teachers' surprise, extraordinary unexpected creativity, freshness of mind, intellectual courage and reflectiveness resources in children (most notably in those who usually refrained from speaking or involving in class activities) when engaged in collective efforts to explore philosophical issues (expressed in concepts and language adapted to their age). In every single case, the classes were organized as incipient communities of inquiry, whose stable and long-term structure is essential to the collective dialogical and shared effort to discover and understand important issues by re-thinking them socially as a joint effort. The results were often far beyond in depth and complexity than the sum of the children's individual thinking, and an open-ended food for everevolving thought. Our experience sustains Lipman's claim that "the progress of a community of inquiry is guided by the Gestalt quality of the unique, immediately experienced inquiry situation."13

In order to optimize the facilitation process, the educational-relational and communicational space was organized so as to allow permanent visual eye-contact between the members, always as circular structure without benches, in order to allow a colloquial registry of confidentiality and action. ${ }^{14}$ The number of participants, never exceeding eighteen students, could be harmoniously and equidistantly placed, turning the inner circular space into the intersubjective dialogical zone of everyone and all. Within this structure, the role of the educator/facilitator is not one of knowledge and competences transmitter, but of an integral part of the community of inquiry; not as a person invested with power,

\footnotetext{
${ }^{11}$ Daniela Dumitru,"An innovative method to teach. Communities of inquiry," research paper (West University of Timisoara, 2012), www.pr-ong.ro/.../An\%20innovative\%20method (accessed December 12, 2015).

${ }^{12}$ http://www.p4c.org.nz/About_P4C.php (accessed June 6, 2015).

${ }^{13}$ Lipman, Sharp and Oscanan, 86. The stories, methodologies and other resources were translated and adapted from numerous portals such as www.sapere.org.uk; www.P4C.com; www.montclair.edu/iapc; http://www.dialogueworks.co.uk; https://www.tes.com/teaching-resources; http://teachertools.londongt.org/ index.php?page $=$ philosophy For Children; http://www.oxfam.org.uk/education/resources; http://www.learnnc.org/lp/editions/philosophy-resources/7643; and many others.

${ }^{14}$ Casarin: 88.
} 
but a member with an equal role in the group, able to engage with the others in a confidential way; and showing the ability to attentively recognize the distinct identity and value the talents of each participant.

Without imposing themselves, the facilitator becomes a model not by prescribing rules, but by obtaining the agreement that everyone intervenes by raising their hand, listens to the argument of the others and does not emit value judgments. S/he listens, never provides answers, speeds up or refocuses the discussion in case it disperses and loses sight of the problem in question; summarizes periodically discussions' shared conclusions or main points expressed; asks for and encourages the requesting of reasons/arguments for the positions expressed by the participants; carefully asks questions aiming to raise awareness and clarification of the question(s) debated, even if only to leave them open for further deepening if the session's time or dynamic will not momentarily allow further exploration of the topic(s).

However, by becoming an equal member of the group, the teacher/ facilitator keeps an "evading" side of their function in the sense that they do not develop spontaneous childish egoism but, in acting as model, they lay the ground for the development of self-discipline, and capacity of self-regulation. What we introduced to groups as philosophical questions-, or problems-generating material (adapted to each specific age-group), were stories, films, or images specially designed by authors specialized in philosophy with children which the participants are invited to investigate by structured and progressive exploratory questions. The narratives and images that present problematic situations emerging from everyday experience, are subjected to interpretation through collectively shared reflection mainly by identifying issues of a philosophical nature - like those enumerated above - and exploring their logical entailments.

The cognitive skills that members of a community of inquiry start developing (sometimes at an astonishing pace) include: evaluating reasons and arguments; exploring and analyzing concepts; drawing inferences; identifying underlying suppositions and assumptions; making distinctions; seeing connections; identifying fallacies; testing generalizations; formulating questions; clarifying ideas; constructing arguments; refining and modifying arguments in response to criticism; recognizing implications: theoretical and practical; finding examples and counter examples; finding analogies and disanalogies; seeing broader perspectives; formulating and testing criteria; being consistent; sticking to the point; and self-correction. ${ }^{15}$

As for the co-operative skills these sessions encourage and entail (and which generally children love to discover and develop in themselves), we were soon able to observe children's progressive opening toward attitudes such as listening to others; open mindedness; treating others' views with respect; building on others' ideas; confident self-expression; being willing to offer, accept and respond to criticism; becoming committed to inquiry; developing intellectual courage ${ }^{16}$ and manifesting a gradual increasing of intercultural sensitivity. ${ }^{17}$

On the other hand, as our own $\mathrm{PwC}$ facilitating exercises confirmed, there are members of the groups who do not necessarily and immediately, or even later on, easily join the thinking-out-loud discussions. As the Columbia University professor Justus Buchler rightfully observed, in case of some students, the individual, not the group, ,participation ${ }^{\text {ee }}$ in the discussion does not necessarily take the form of oral activity. The educator/facilitator's concern should also be that of allowing this process to happen:

Every class exhibits wide differences in the emotional makeup of its members, and the shy, reticent, or modest student may profit greatly from discussion by others [...] The student who participates through reflective activity alone is not shirking the collaborative obligation of the group as the chronic absentee is. Such students are, as it were, creative

\footnotetext{
${ }^{15}$ http://www.p4c.org.nz/About_P4C.php.

${ }_{16}$ Ibid.

17 Damian Spiteri, “'The Community of Philosophical Inquiry' and the Enhancement of intercultural Sensitivity," Childhood \& philosophy, Rio de Janeiro 6 (11), Jan./Jun. 2010, http://www.periodicos. proped.pro.br/index.php?journal=childhood\&page=article\&op=viewFile\&path $\% 5 \mathrm{~B} \% 5 \mathrm{D}=590 \&$ path $\% 5 \mathrm{~B} \% 5 \mathrm{D}=4$ $\underline{86}$ (accessed June 26, 2015).
} 
auditors in the community of query. The problem of self-confidence is one that they must solve for themselves and the teacher can help by lifting from them the tension that comes with external pressure. The „responsibilities of communal participation ${ }^{\text {ee }}$ must not, therefore, be construed as a yoke; they can be fulfilled in more than one way. ${ }^{18}$

\section{A locally adapted solution: a PwC/P4C postgraduate programme}

In trying to respond to these complex needs, the programme contains two general introductory topics aimed at giving the students-educators a theoretical introduction to philosophy for children (Foundations of Philosophy for Children) and a methodology of working with specific texts and materials adapted to different ages of children (Psychopedagogy of reading) and 26 philosophical themes categorized according to the specific P4C literature, i.e. Ethics; Social and political philosophy; Metaphysics; Philosophy of Mind; Environmental Ethics; Epistemology; Philosophy of Language; Logic; Aesthetics; Courage; Will Power; Attitude; Friendship; Happiness; Rights; Ethical Dilemma; The Environment; Personal Identity; Possibility and Necessity; Essentialism; Philosophy of Religion; Knowledge; Justification of Belief; Truth; Can Conscious Machines Exist?; Skepticism and Solipsism.

In terms of themes per se, the course is structured in three modules:

1. Introduction to philosophy adapted for children

2. Applied ethics adapted for children.

3. Metaphysics and Epistemology adapted for children.

The principles underlying the themes and methodology of working with pupils we adopted (and adapted to the national and regional context), are articulated in simple practices developed by highly experienced and high performing educational organizations such as SAPERE, which, if consistently followed within the communities of inquiry, will help children and young people to become aware, curious and reasonable. These principles include the following:

- Correct thinking is learned through dialogue with others

- Children need to participate in dialogues that provide examples and models of good thinking.

- Questioning is a continuing source of knowledge and intellectual excitement.

- In order to be well founded claims need to be tested through disputes. The dispute is conceived not as an argument but as a collaborative search of the best response to a question.

- To think well is to be both creative and critical. Creative thinkers make connections, speculate and explore alternatives.

- Good thinking depends on attitudes and skills. Children should be encouraged to be as reasonable as possible.

- Learners will be shown, with the help theory and especially applications, the importance and usefulness for children and adults of talking together about philosophical questions that matter to them and make the connection between thinking about one area or another of experience and thinking about the experience as a whole. ${ }^{19}$

The 4 practices - underlying each theme - through which the students will learn to apply the above principles, can be briefly described as follows:

1. Facilitating and encouraging questioning;

2. Facilitating and encouraging dialogue and argumentation;

3. Co-operative development of concepts;

\footnotetext{
${ }^{18}$ Justus Buchler, "What is a discussion?" in Thinking children and education, ed. M. Lipman (Iowa: Kendall \& Hunt Publishing, 1993), 528.

${ }^{19} \mathrm{http}: / / \mathrm{p} 4 \mathrm{c} . \mathrm{com} /$ teachers-guide.
} 


\section{Development of a reasonable attitude. ${ }^{20}$}

In terms of state-of-the art research that grounded our view on teaching children thinking skills in social environments, we started by linking our approach to the breakthrough work of Peirce, Dewey, and especially Lipman in the field of social learning and the ways it was expanded to other fields and subjects. At the foundation of our view we placed elements from Lave's and Wenger's theories of communities of practice; Bandura's social learning theories; and Engeström's and Bereiter's innovative knowledge communities, which do not focus on knowledge transfer but on social, intersubjective, competences growth and knowledge creation. In our educational vision we also incorporated elements from John Dewey's theory on practical enquiry and Knowles' social constructivist learning which "view learning as stemming from making experience-based knowledge explicit and focus on reflection on members' knowledge-in-action." ${ }^{21}$ Our resulting guiding principle which we aim to persistently convey to the education policies-makers and to society in general is congruent with the idea so well synthetized by Robert Fisher:

The challenge to improve children's thinking, learning and language lies at the heart of education. It also lies at the heart of the world-wide philosophy for children movement, which uses philosophical enquiry to enhance the thinking, learning and language skills of students of all ages and abilities in more than thirty countries around the world. ${ }^{22}$

\section{References}

Bereiter, Carl. Education and mind in the knowledge age. Mahwah, NJ: Lawrence Erlbaum Associates, 2002.

Buchler, Justus, "What is a discussion?" in Thinking children and education, ed. M. Lipman. Iowa: Kendall \& Hunt Publishing, 1993.

Casarin, Pierpaolo. "The fifth national training course in 'Philosophy for Children." Pratiche filosofiche 1(2) Oct (2003): 87-91.

Dewey, John. Logic: The Theory of Inquiry. New York: Holt, 1938.

Dumitru, Daniela. "An innovative method to teach. Communities of inquiry." Research paper (West University of Timisoara, 2012), www.pr-ong.ro/.../An\%20innovative\%20method (accessed December 12, 2013).

Dumitru, Daniela. "Communities of inquiry. A method to teach." Procedia - Social and Behavioral Sciences 33 (2012): 238-242.

Engeström, Yrjö. "Innovative learning in work teams." In Perspectives on activity theory, ed. Y. Engeström et al., 377-404. Cambridge: Cambridge University Press, 1999.

Fisher, Robert. Teaching Thinking: Philosophical Enquiry in the Classroom. London \& New York: Continuum, 2001.

Gerber, Scott. "Here is the real problem with the American educational system." Time, 2 June 2014, http://time.com/2806663/american-education/ (accessed June 20, 2015).

Hannam, Patricia, and Echeverria, Eugenio. Philosophy with Teenagers: Nurturing a moral imagination for the $21^{\text {st }}$ century. New York and London: Network Continuum, 2009.

Knowles, M.S. Holton, E.F. and Swanson, R.A. The Adult Learner: The Definitive Classic in Adult Education and Human Resource Development. $5^{\text {th }}$ Edition. Oxford: Butterwirth-Heinemann, 1998.

Lave, Jean. A comparative approach to educational forms and learning processes. Anthropology and Education Quarterly. 13(2) 1982: 181-187.

\footnotetext{
${ }^{20}$ Ibid.

${ }^{21}$ Daniela Dumitru, "Communities of inquiry. A method to teach," Procedia - Social and Behavioral Sciences 33 (2012): 240.

${ }^{22}$ Robert Fisher, Teaching Thinking: Philosophical Enquiry in the Classroom (London \& New York: Continuum), 1.
} 
Lave, Jean, Wenger, Etienne. Situated Learning, 24th edition. Cambridge: Cambridge University Press, 2011.

Lipman, Matthew, Sharp, A.M., Oscanyan, F. S. Philosophy in the Classroom. 2nd edition. Philadelphia: Temple University Press, 1980.

Lipman, Matthew. Thinking in Education. Cambridge: Cambridge University Press, 2003.

Martin, R. P. "The Pedagogy of Philosophy for Children/Philosophical Enquiry." Research paper (University of York, 2012), http://etheses.whiterose.ac.uk/3971/1/MRPaineMAeducDisV3.pdf (accessed December 1, 2015)

Spiteri, Damian. (2010). The Community of Philosophical Inquiry and the Enhancement of intercultural Sensitivity. Childhood \& philosophy. Rio de Janeiro 6 (11), Jan./Jun. 2010, http://www.periodicos.proped.pro.br/index.php?journal=childhood\&page=article\&op=view File\&path\%5B\%5D=590\&path\%5B\%5D=486 (accessed June 26, 2015).

Wenger, Etienne, Communities of Practice. Cambridge: Cambridge University Press, 2008.

www. p4c.com/teachers-guide

http://www.apus.edu/ctl/faculty/community-of-inquiry

www.sapere.org.uk

www.montclair.edu/iapc

http://www.dialogueworks.co.uk/

https://www.tes.com/teaching-resources/

http://teachertools.londongt.org/ index.php?page= philosophy For Children

http://www.oxfam.org.uk/education/resources

http://www.learnnc.org/lp/editions/philosophy-resources/7643. 